\title{
RESEARCH ON INVESTMENT RISK INFLUENCE FACTORS OF PREFABRICATED BUILDING PROJECTS
}

\author{
Xiao-Juan LI $\mathbb{1}^{*}$ \\ College of Transportation and Civil Engineering, Fujian Agriculture and Forestry University, \\ Fuzhou, 350108, Fujian Province, P.R. China
}

Received 28 August 2019; accepted 21 May 2020

\begin{abstract}
Prefabricated construction is an effective and efficient approach to improve construction processes, productivity, quality, and cost-effectiveness. There are, however, practical problems in this approach, including higher risk levels, and cost and time overruns. This study aims to develop a systematic approach for determining the key factors that affect investment risk of prefabricated building projects and assess this risk. Based on literature review, a structured questionnaire was distributed to 210 China-based construction organizations. Relevant evaluation index weights were obtained via questionnaire, and the application of structural equation modelling led to quantitative evaluation of investment risk in the prefabricated construction industry. The results show that the following systems have the most influence on investment risk (from high to low): economy, technology, market, management, and policy, and that the investment risk of such projects can be assessed using structural equation modelling. Relevant measures are presented to guide investment risk evaluation of projects. This study contributes to literature by considering investment risk influencing factors in this field. Further, the findings can help in understanding the implementation and investment risk control of prefabricated building projects, while providing valuable information to departments that make decisions on improving investment risk performance of such projects.
\end{abstract}

Keywords: prefabricated buildings, investment risk, risk evaluation, risk management, structural equation model (SEM), construction industry, China.

\section{Introduction}

Prefabricated buildings refer to buildings that are assembled using factory-produced prefabricated components after their delivery at the construction site (Nistico et al., 2015). Compared to traditional buildings, prefabricated ones have advantages in terms of improved construction quality, reduced labor requirements, and lower environmental impact (Ng \& Loosemore, 2007). The development of the prefabricated building industry in China, including its associated processes, is still in its early stage. However, the implementation of this policy is expected to significantly increase the scale of such projects in the future. The State Council of China has formally issued several proposals (released on February 6, 2016) regarding construction management to further strengthen urban planning, which state that China "will strive for a period of approximately 10 years to make prefabricated buildings account for $30 \%$ of new constructions". Prefabricated construction is regarded as an effective and efficient approach to improve construction processes and productivity, thereby ensuring better construction quality and reduced time and cost. Without the implementation of sufficient risk management measures, investment in prefabricated building projects may face severe risk, due to the uncertainty of future investment income and possible loss of the investment principal (Kaliszewski, 2019). Although prefabricated building projects have been accepted and adopted by the global construction industry, investment risk assessment of such projects is still in its infancy (Qi \& Zhu, 2015; Hong et al., 2018). At present, most research on risk management of such projects is based on various risk assessment theories in combination with engineering examples; however, there is less evaluation of investment risk in such projects. Therefore, it is important to highlight the sources of risk in the investment process of such projects, and to establish an investment risk assessment system that minimizes the risk involved in this process.

${ }^{*}$ Corresponding author. E-mail: xiaojuanli@fafu.edu.cn 
Risk assessment (RIA) refers to the quantified effects and possibilities of loss of human and animal life, property damage, and other consequences, before and after the occurrence of a potential risk event (Ye \& Tiong, 2003). RIA is necessary to quantify the degree of impact or loss that may be caused by an event or an object. As the current investment risk guidelines are insufficient for addressing the requirements of prefabricated building construction (Li et al., 2017a), it is necessary to establish an accurate investment risk assessment system to accurately judge the degree of risk during such construction.

Establishing a risk assessment system, specifically to address the investment risk of prefabricated building projects, requires conducting a thorough risk analysis and a comprehensive assessment of the construction investment, which can ensure strong risk control and aid in determining preventative measures. Through the implementation of such measures, we can avoid investment risk problems that can hinder a prefabricated building project, while an accurate investment risk evaluation can ensure project efficiency and further promote industrialization of the construction sector (Huang et al., 2013). However, there is a research gap in the knowledge regarding investment risk evaluation of prefabricated building projects. There are several methods of evaluation (such as quantitative and qualitative) and there are various methods for conducting RIA, including fuzzy comprehensive assessment, clustering analysis, hierarchical analysis, fuzzy analytic hierarchy process, Grey system theory sensitivity analysis, and factor analysis (Fischinger et al., 2009; Pinto, 2014). These methods have been used to identify and evaluate the construction risks of prefabricated structures in the past. Although these methods can incorporate uncertainty in the information flow during the process of RIA as well as include any obfuscation of directional indexes, they cannot be used to make a comprehensive and objective assessment of randomness in the uncertainties (Wei et al., 2005; Wu et al., 2017; Xiong et al., 2013). Among these assessment methods, an analytic hierarchy process offers simplicity and practicality. However, this method provides approximate results and is greatly influenced by subjective factors. Accident risk probability analysis is based on large volume of accident data, but there are relatively few prefabricated building projects in their early stages. Cluster system analysis can be used to determine similar relationships between classes but it cannot be used to solve the problem of optimal ranking within the same class. The advantage of the clustering analysis model is that it provides an intuitive and concise conclusion; however, its disadvantage is that it is difficult to obtain a clustering conclusion when the sample size is large. The fuzzy comprehensive assessment method can lead to a scientific quantitative assessment, but it is easy to obtain a poor resolution, or even a failed multi-index assessment. A sensitivity analysis plays a significant role in developing a risk plan; however, the calculation is monotonous and the data are irregular, which may result in contradictory assessment results. Although the advantage of applying a factor analysis to the simplification and integration of the data is evident, the use of the least squares method may result in a failed outcome. Considering these shortcomings, we use the structural equation model (SEM) in our study.

The SEM is a statistical technique used for testing and estimating causal relationships through a combination of statistical data and qualitative causal assumptions, which makes up for the shortcomings of the above methods. This view of the SEM was articulated by the geneticist Wright (1921) and the economist Haavelmo (1943), and it was formally defined by Pearl (2009) using the calculus of counterfactuals. Relevant research efforts using the SEM have also been undertaken in the construction field. The factors influencing the downtime consequences of construction equipment were characterized and quantified based on the SEM (Hong et al., 2018). According to Molenaar et al. (2000), the SEM can be used to describe and quantify the fundamental factors that affect contract disputes between owners and contractors in the construction industry (Molenaar et al., 2000). Furthermore, Debrezion et al. (2007) used SEM to study the impact of railway stations on property values. Their findings showed that commuter railway stations have a significantly higher impact on property values as compared to light- or heavy-traffic railway stations (Debrezion et al., 2007). Cho et al. (2009) used factor analysis and SEM to deduce the overall causal relationship and level of influence among project characteristics, owner characteristics, contractor characteristics, environment characteristics, and five more categories of project performance, including construction costs and time.

This paper summarizes the qualitative evaluation systems used in the literature and quantifies this evaluation through a questionnaire and the SEM to provide a more robust framework for the comparison and selection of investment schemes. This study explores the factors of an investment risk evaluation system from the policy, market, technology, economy, and management perspectives, and proposes an assessment method that can help evaluate investment risk. The findings contribute to the existing knowledge of investment risk assessment by focusing on prefabricated building projects. The study also summarizes the lessons and experiences gained from current prefabricated building projects, and provides insights for industry practitioners who seek to adopt an investment risk assessment method.

\section{Literature review}

The prefabricated building form has been widely used in many regions around the world, such as Japan, Europe, and North America. Scholars have extensively studied its supply chain and the assessment of its construction risk. Stroebele et al. (2017) analyzed the influencing factors and management methods of the assembled residential supply chain, offering corresponding countermeasures. Zhong et al. (2017) discussed the role of Internet of Things in the promotion of prefabricated buildings. Rose (2012) dis- 
cussed the case of a Swedish prefabricated project with interactive research technology to explain the risk of precast construction and have proposed a corresponding solution.

Research on prefabricated buildings in China has grown significantly over the years. Zhang (2014) studied the influence of two aspects of policy and enterprise internal management on the investment risk of prefabricated building projects and used the analytic hierarchy process (AHP) to obtain the corresponding investment risk evaluation system. Starting from the prestressed concrete rates for prefabricated buildings, Cheng (2017) analyzed the difference in the precast cost between reinforced concrete and regular concrete, and proposed measures to reduce subsequent investment costs. Li (2017) pointed out the economic benefits from the increase in the acquisition rate of fabricated steel structures for housing and explained its influence on the investment cost from a policy and structural scheme perspective. Contrary to several common risk assessment methods, Chen (2017) developed the AHP-Fuzzy comprehensive evaluation model and described the risk management dynamics of prefabricated buildings in four stages. Qi et al. (2016) provided a comprehensive explanation of the life cycle risk identification of the prefabricated building by using entropy and expert scoring methods and comparing the index size of each influencing factor.

The research above (Stroebele et al., 2017; Zhong et al., 2017; Rose, 2012; Zhang, 2014; Cheng, 2017; Li, 2017; Chen et al., 2017; Qi et al., 2016) shows that the influencing factors only consider policy and management, or politics and economy, and thus cannot comprehensively analyze the investment risk of prefabricated buildings. This study is different from previous studies on this topic, as it aims to study, based on existing literature (Chen et al., 2017; Wen, 2016), the risk factors from the policy, market, technical, economic, and managerial perspectives, as possible influencers of investment risk of prefabricated building projects.

\subsection{Analysis of policy risk factors}

\subsubsection{Incentive policy factors}

All provinces and cities in China receive subsidies and incentives for fabricated projects, such as volume rate rewards, area subsidies, land priority transfers, equipment fund subsidies, and tax relief (Li et al., 2017a). The incentive policy compensates developers for the incremental cost of the implementation of prefabricated structures and thus, the impact of investment risk is offset to a certain extent (Li et al., 2017b).

\subsubsection{Mandatory policy factors}

Coercive policies also play an important role within this topic. In the early stages of industrialization, the mandatory use of fabricated construction projects was mostly funded by affordable housing or public rental housing (Li et al., 2016). The most significant impact of coercive policies is on investment risk. Traditional buildings charge
$11 \%$ in value-added taxes (revenues) and the value-added process of the prefabricated components in the factory implies that the components are also subject to taxes (Burtonshaw-Gunn, 2017). Therefore, there is an increased tax burden and the higher the prefabricated rate, the heavier is the tax burden.

\subsection{Analysis of market risk factors}

\subsubsection{Market acceptance}

Market acceptability can be classified into industry acceptance and consumer acceptance (Cen \& Liu, 2016; Tian et al., 2016). Although the prefabricated building may be ecologically friendly, efficient, and safe, it is difficult to decrease the construction cost in the short term. At present, along with the increasing cost of building such projects, there are additional costs for exploration and adaptation of industrial transformation, as well as "learning costs", which means that unpredictable losses are likely (Lai, 2018). Whether this is acceptable to developers or construction units is yet to be evaluated.

In consumer groups, the strength of prefabricated buildings is not good enough. In building networks and other related forums, we see that many users have doubts about the safety of prefabricated components; a subsequent challenge is how to ensure or possibly improve the stability of the building while reducing the time limit for prefabricated building projects (Li et al., 2014). In addition, prefabricated buildings offer limited diversity, are single in mode, and are more suitable for residential purposes; thus, it is difficult to completely meet the individual needs of modern consumers.

\subsubsection{Integrity of the industrial chain}

Prefabricated buildings have yet to form a one-button supply chain from the perspective of planning and design, material supply, component production, and project construction. As with traditional buildings, the cost of prefabricated buildings is greatly influenced by the change in market price of raw materials such as steel and cement. Manufacturers of some materials of PC components may also end up monopolizing the segment, for example, if the PC component prefabrication plant is in an early stage, regional development is uneven, the transregional choice of transportation is very expensive, and other options are not economically viable, then price-based monopoly is possible and this can increase budget costs.

\subsubsection{Similar product cost performance}

Traditional buildings meet user requirements of comfort, functional integrity, and building safety. The price of prefabricated buildings is higher than traditional buildings because of their high cost of development, but they offer the advantage of high thermal insulation performance of the precast wall and subsequent reduction in energy consumption. These effects cannot usually be accurately reflected in the short term and, thus, the competitive advantage is not immediately obvious. 


\subsection{Analysis of technical risk factors}

The technical risks of prefabricated buildings have the following four aspects.

\subsubsection{Quality risk}

Quality problems that may occur in the manufacturing of components include size deviation of components, positional deviation of the reinforcing bar and embedded parts, or more serious problems such as leakage of tendons and cracks due to improper concrete pouring and maintenance (Kaliszewski, 2019). Solutions to such problems can be guaranteed by contracts, but within acceptable range; errors in components, however, will increase the difficulty of construction later on, and may even delay the project.

\subsubsection{Design risk}

First, we address the risk related to the prefabrication design.

The investment risk of prefabricated building projects is related to the various parameters of the project. Taking the common prefabricated steel structure and prefabricated-reinforced concrete as an example, the cost of the prefabricated steel structure is high, but the structure is large, the bearing capacity must be strong, the space arrangement are more operational, and the area rate is large (Wang et al., 2019). The rate of return on investment is thus increased, but the components for the latter need to be processed using high-temperature steam in factories, implying that it will increase the demand for coal and electricity as well as carbon emissions linked to concrete.

Second, we address the risk related to the PC rate of the building. The cost of flat production is $20 \%$, which is higher than that of traditional buildings, and it has increased by $360-450$ yuan per square meter. With an increase in the prefabrication rate, the corresponding cost component will also increase (Pinto, 2014).

Third, we discuss the risk related to the scale of the project and the replication rate of the floor. According to this study, when the prefabricated project reaches 100 thousand square meters in volume, the unit cost equals that of traditional buildings, and the comparative advantage becomes more obvious. The rate of floor replication is also an important factor in investment, because when the rate of single floor duplication is high, the component can be produced in batches, the production cost of unit component is reduced, and the rate of return of the project increases.

Fourth, we address the design integration risk. Integrated design and integrated construction are the future of prefabricated buildings. In traditional architecture and construction, the design of civil engineering, reinforcement, installation, and decoration often requires carrying out collision tests to ensure the operability of construction according to plan. In the design of prefabricated components, the accuracy of reserved holes and the position of joints between the components are very important, as this directly affects the production of the components (Inozemtcev \& Duong, 2019). If the level of integrated design is insufficient and the design changes frequently, the direct cost of production and construction will increase (Zhong et al., 2017).

Fifth, we discuss the constructability risk of the design. In addition to the aforementioned parameters, the design of key points such as the arrangement of the hoisting point and the connection mode of the components should consider the operability of the actual construction (Luo et al., 2015). Hoisting lifting points is not sufficient according to theory, and the characteristics of the existing lifting machinery should be considered. The number and position of lifting points should be properly arranged to avoid problems in lifting of the crane and affecting the time limit involved. In addition, the design of connections between components should be very simple. Taking external wall connections as an example, there are external and side connections in which the construction and installation errors of the side connection are high, leading to difficulty in construction and the possibility of damage to the components (Zhao et al., 2019). A subsequent delay in the time limit can lead to damage to the components causing a rise in the cost (Zhang, 2014).

\subsubsection{Transportation risk}

The PC component is the finished or semi-finished product of the construction department's components. Its quality is strong, it has large volume, and the risk of transportation loss is higher than that for ordinary building materials (Luo, 2019). During transportation, the layout, fixing, and protection measures must be carried out accurately and rigorously, as this ensures that the components are intact when transported to the scene.

\subsubsection{Construction risk}

1) The risk of component stacking and protection

At the site of a fabricated project in Shanghai, there are only three patents for the stacking of prefabricated parts, which explains its high requirements (Chang $\& \mathrm{Wu}, 2019$ ). The components are transported to the construction site, where some are temporarily placed. The corresponding temporary support and fixed facilities should be set up when stacking. At the same time, concrete components require certain humidity for subsequent maintenance, and improper measures may cause construction accidents.

\section{2) The risk of hoisting construction}

There are three main sources of construction risk of components (Iqbal et al., 2015). First, the management personnel may fail to make progress and construction planning according to the technical features of the project and prefabricated components, which may thus cause complications in construction. Second, there may be a lack of experience in motivating the construction personnel, and the actual construction may deviate from expected goals. Finally, similar to traditional building risks, 
the strength of the cast-in-place concrete and the grouting material is significant. In a prefabricated building project, the strength of the cast-in-place concrete and the grouting material will not only cause quality problems in later use, but also affect the tightness of the connection between the components and cause secondary accidents.

\subsection{Analysis of economic risk factors}

\subsubsection{Investment estimate risk}

Under the premise that quota standards are not perfect, the accuracy of the bill of quantities calculation cannot be guaranteed, and there is a possibility of deviation in the investment estimation (Wang et al., 2018). As the capital demand in construction projects is generally large, most of these funds come from bank loans. When the actual investment exceeds the estimated range of investment, the difficulty of raising additional funds increases, affecting the interest risk and other economic indicators.

\subsubsection{Financing risk}

Financing risk refers to the difficulty of estimating the rate of return on capital when funds are raised, and enterprises may be faced with the risk of declining returns or even loss in investment projects. The construction project, often large in scale, involves large amounts of capital and long turnover periods. Particularly in the installation of construction projects, the initial investment and one-time cost is higher than that in traditional construction projects, therefore, relying on financing to solve the shortage of funds leads to higher risks (Liu, 2013).

\subsection{Analysis of managerial risk factors}

\subsubsection{Contract risk}

Contracts are essentially the result of communication and coordination between construction projects and enterprises. The contract terms and the formulation of treaties to protect the rights and interests of enterprises can reduce the risks involved, based on adequate communication and coordination.

\subsubsection{Project management risk}

The role of project management includes project decisionmaking, design management, and preliminary preparation. Project management risk covers two levels, namely project management methods and the experience and quality level of project management personnel.

An unreasonable project management method would negatively affect the feasibility and effectiveness of the project, and ultimately affect the comprehensive effort (Gang, 2016). The project management method of prefabricated buildings should not completely follow the methods in traditional construction, as the standard system of quality management and safety management needs to be evaluated (Zhang \& Zheng, 2015).
The level of the project manager is also important. At the beginning of the development of the project, the lack of experienced managers is the main problem. Facing problems in project operation planning, it is difficult to achieve a full range of countermeasures, which may exacerbate the risk factors.

\subsection{A summary of investment risk analysis}

The risks associated with the design, component production and transportation, and construction plans, have led to the shift of investment risk from the construction section to the production section. In the feasibility assessment of construction, shortening the construction period implies shortening the investment period and saving financing costs, while the feasibility of economic evaluation is reduced.

Risks in design, component production, transportation, construction, and operation imply contract and insurance control issues in project investment. In a highrisk scenario, the choice of the contract type, the contract content and terms, and the selection of the corresponding insurance scheme may have a significant influence on risk assessment.

\section{Research methodology}

\subsection{Structural Equation Model (SEM)}

The SEM is a research method for statistical analysis, which can be used to process complex multi-variable research data (Liu et al., 2017). It can estimate potential variables, complex independent variables, or a dependent variable prediction model by examining the relationship between various factors.

The SEM includes measurement and structural models; the measurement model refers to the relationship between potential variables and observed variables while the structural model refers to the relationship between potential variables (Zheng et al., 2016). Potential variables are not measurable and are usually represented by ellipses. Observation variables, also known as measurement variables or dominant variables can be measured by direct means and are generally expressed as rectangles (Zheng et al., 2016).

\subsubsection{Measurement model}

In the measurement model, the assumed construct cannot be directly measured but can be a trait or an abstract concept; therefore, the observed, recorded, and summarized data and the measured data can be built into the potential variables by using the measurement model, generally expressed by the following matrix equation.

A measurement equation for independent variables:

$$
X=\Lambda_{X} \xi+\delta \text {. }
$$

A measurement equation for dependent variables:

$Y=\Lambda_{Y} \eta+\varepsilon$. 

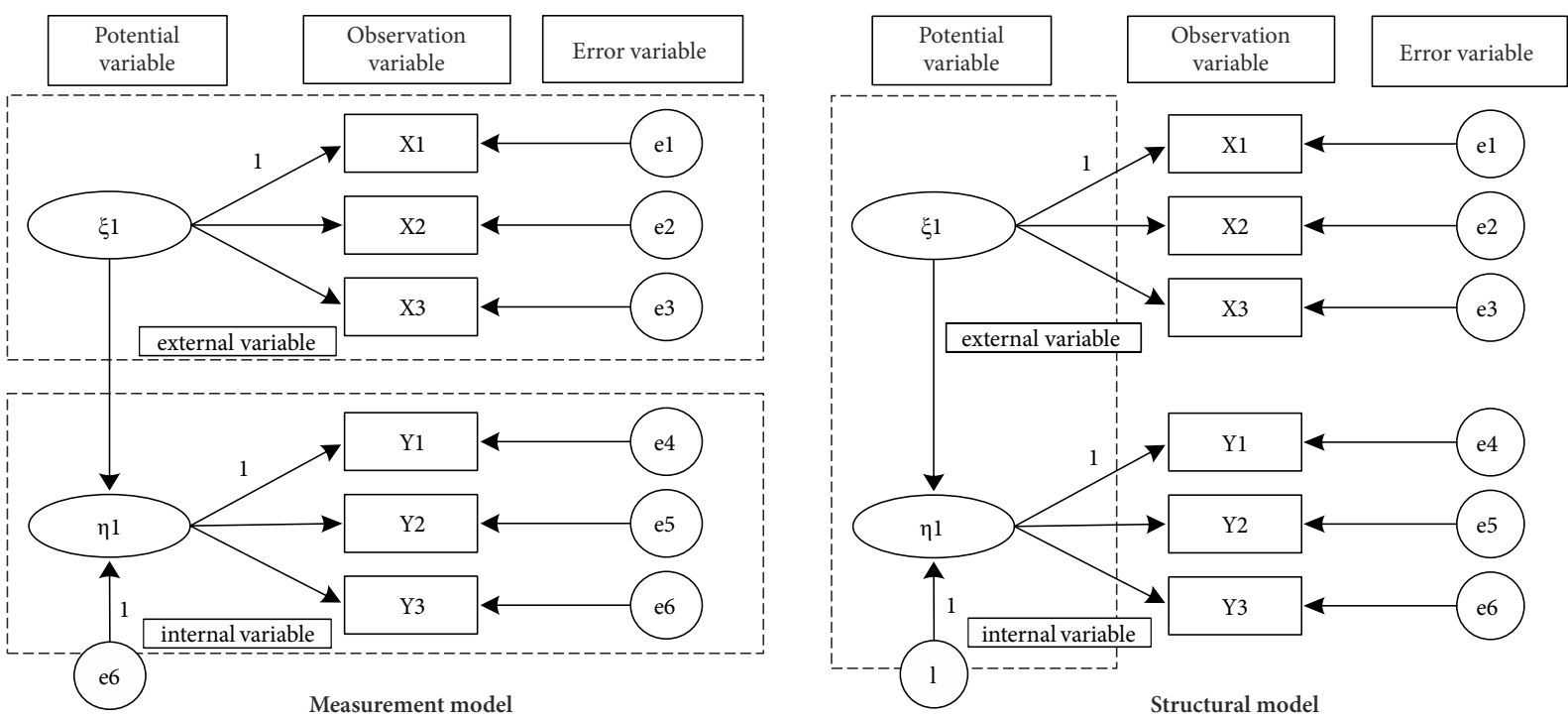

Figure 1. Measurement model and structural model

\subsubsection{Structural model}

The structural model shows the causal relationship of potential variables:

$$
\eta=\Gamma \xi+\beta \eta+\varsigma .
$$

The relationship between the measurement model and the structural model is shown in Figure 1.

\subsubsection{Model construction}

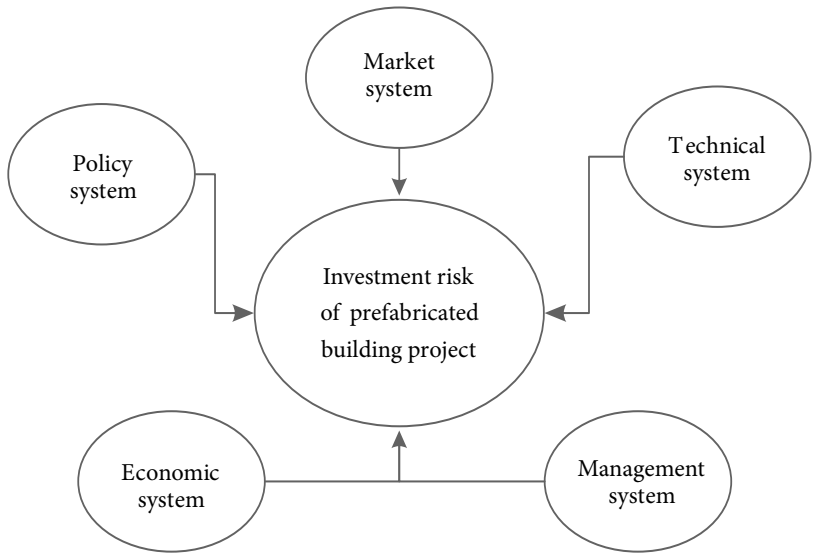

Figure 2. Structural model of construction risk assessment for prefabricated building projects

\subsubsection{Assumptions of the model}

The SEM helps to establish the investment risk of prefabricated building projects. According to the evaluation index system discussed above, there are five latent variables in this model, namely policy system, market system, technical system, economic system, and management system. The path relationship diagram is shown in Figure 2.

The policy system includes three secondary indicators, namely the four measurable variables of the degree of perfection of relevant laws, implementation of incentives or mandatory policies, and the sustainability and stability of the policy. The market system factors include three secondary indicators, namely market acceptance, industrial chain integrity, and price ratio of the same product. The technical system factors consist of three secondary indicators, namely maneuverability of design, transportation, and construction schemes, integrity of the modular system, and quality standard of technical personnel. The economic system also has three secondary indicators, namely three measurable variables of initial one-time cost and fund recovery period, a lack of lists and quotas, and limitations of developer financing and consumer loan channels. The management system is composed of three secondary indicators, namely project participation in communication and coordination among enterprises, project management method for prefabricated building projects, and management staff's experience and quality level.

We thus develop the following hypotheses to be tested in this study:

H1: Policy system risks have a significant impact on the investment risk of prefabricated building projects.

H1a: The degree of perfection of relevant laws has a significant influence on policy system risk.

H1b: Implementation of incentives or mandatory policies has a significant influence on policy system risk.

H1c: The sustainability and stability of policy has a significant influence on policy system risk.

$\mathrm{H} 2$ : Market system risk has a significant impact on the investment risk of prefabricated building projects.

H2a: Market acceptance has a significant impact on market system risk.

$\mathrm{H} 2 \mathrm{~b}$ : Industrial chain integrity has a significant impact on market system risk.

$\mathrm{H} 2 \mathrm{c}$ : The price ratio of the same product has a significant impact on market system risk.

H3: Technical system risk has a significant impact on the investment risk of prefabricated building projects. 
H3a: The maneuverability of design, transportation, and construction schemes have significant impact on technical system risk.

H3b: The integrity of the modular system of the Ministry has a significant impact on technical system risk.

H3c: The quality standard of technical personnel has significant impact on technical system risk.

$\mathrm{H} 4$ : Economic system risk has a significant impact on the investment risk of prefabricated building projects.

H4a: Initial one-time cost and fund recovery period has a significant impact on economic system risk.

H4b: A lack of lists and quotas has a significant impact on economic system risk.

H4c: Limitations of developer financing and consumer loan channels has a significant impact on economic system risk.

H5: Management system risk has a significant impact on the investment risk of prefabricated building projects.

H5a: Project participation in communication and coordination among enterprises significantly influences management system risk.

H5b: Project management method for prefabricated building projects has a significant influence on management system risk.

H5c: Management staff's experience and quality level has a significant impact on management system risk.

\subsubsection{Model identification}

The identifiability of the model should be considered before analysis; otherwise, the corresponding parameter value cannot be estimated. Bollen (1989) put forward the " $t$ " rule, which determines the recognizability of the model.
Here, $t$ is the number of freely estimated parameters. If $t$ is less than $D P$ (number of measured data points), this represents excessive identification; when the two numbers are equal, this means sufficient recognition. If $t$ is greater than $D P$, this means insufficient recognition, thus increasing the constraint conditions. The test formula is as follows:

$$
D P=\frac{(p+q)(p+q+1)}{2} .
$$

The number of measured data of the hypothesized model $D P=22 * 23 / 2=253$, the number of freely estimated parameters $t=54$, hence $t<D P$, thus indicating overidentification and confirming that this can be further analyzed.

\subsection{Establishment of investment risk evaluation system}

Based on the theory of the evaluation system of Cheng and Wen, we posit that the investment risk evaluation system of the prefabricated building project is as follows (Chen et al., 2017; Li et al., 2017a, 2017b) (see Table 1).

The investment performance model evaluation method for a prefabricated building project is shown in Figure 3.

\section{Data analysis}

\subsection{Questionnaire information and basic investigation}

This survey adopted the five-point Likert scale to establish an evaluation dimension of 1 to 5 points. This was distributed to industry experts in civil engineering and engineering management fields (Table 2).

Table 1. Investment risk evaluation system for prefabricated building projects

\begin{tabular}{|c|c|c|c|c|}
\hline \multirow{16}{*}{$\begin{array}{l}\text { Investment } \\
\text { risk of } \\
\text { prefabricated } \\
\text { building } \\
\text { projects }\end{array}$} & $\begin{array}{c}\text { First level of } \\
\text { evaluation index } \\
\text { (potential variable) }\end{array}$ & Designate & Second level of evaluation index (observation variable) & Designate \\
\hline & \multirow{3}{*}{ Policy system risk } & & The degree of perfection of relevant laws & A1 \\
\hline & & A & Implementation of incentives or mandatory policies & A2 \\
\hline & & & The sustainability and stability of policy & A3 \\
\hline & \multirow{3}{*}{ Market system risk } & & Market acceptance & B1 \\
\hline & & $\mathrm{B}$ & Industrial chain integrity & B2 \\
\hline & & & The price ratio of the same product & B3 \\
\hline & \multirow{3}{*}{$\begin{array}{l}\text { Technical system } \\
\text { risk }\end{array}$} & & $\begin{array}{l}\text { The maneuverability of design, transportation, and construction } \\
\text { schemes }\end{array}$ & $\mathrm{C} 1$ \\
\hline & & $\mathrm{C}$ & The integrity of the modular system of the Ministry & $\mathrm{C} 2$ \\
\hline & & & Quality standard of technical personnel & $\mathrm{C} 3$ \\
\hline & \multirow{3}{*}{$\begin{array}{l}\text { Economic system } \\
\text { risk }\end{array}$} & & Initial one-time cost and fund recovery period & $\mathrm{D} 1$ \\
\hline & & $\mathrm{D}$ & A lack of lists and quotas & D2 \\
\hline & & & Limitations of developer financing and consumer loan channels & D3 \\
\hline & \multirow{3}{*}{$\begin{array}{l}\text { Management } \\
\text { system risk }\end{array}$} & & $\begin{array}{l}\text { Project participation in communication and coordination among } \\
\text { enterprises }\end{array}$ & E1 \\
\hline & & $\mathrm{E}$ & Project management method for prefabricated building projects & E2 \\
\hline & & & Management staff's experience and quality level & E3 \\
\hline
\end{tabular}




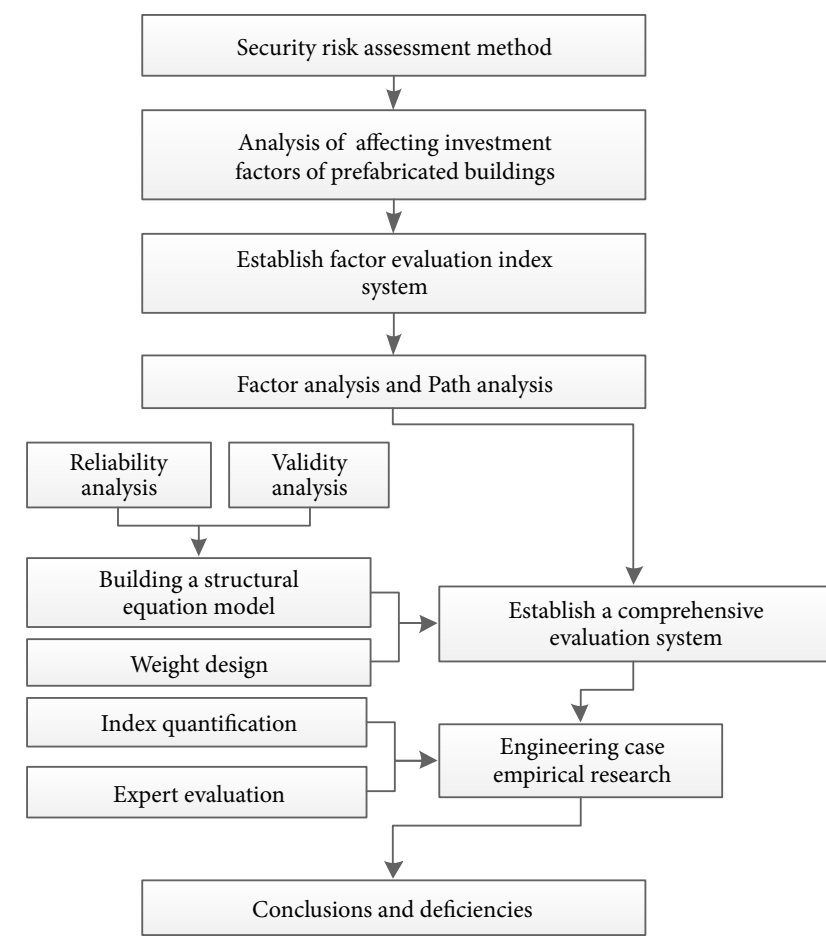

Figure 3. Investment performance model evaluation method for prefabricated building projects

The respondents of this survey were workers engaged in prefabricated building construction, and a summary of their basic details in shown in Table 3. A sample size of at least 100 implies that the maximum likelihood estimation (MLE) method should be used to estimate the structural equation. However, if the sample size is much larger (e.g. 400 to 500), then the MLE method tends to be over-sen- sitive and it may lead to poor results of the fitness index tests (Rong, 2009). Questionnaires are an integral part of such a survey, and its reliability and validity, ensured via compliance, will affect the accuracy and reliability of the results.

The questionnaires were distributed through contacts and networks within the field, and 210 filled copies were collected. Out of these, 176 were valid questionnaires, implying an effective response rate of $83.8 \%$. The uneven distribution of samples implies that it is not enough to describe the problem comprehensively, so it is only used to establish the evaluation model.

\subsection{Analysis of reliability and validity}

This study uses SPSS 22.0 as the software to evaluate Cronbach's alpha, which is as an indicator of sample reliability. The model also uses the overall correlation coefficient CITC value as a supplement to the alpha test. The results are shown in Table 4.

The alpha values of the five potential variables are significantly higher than 0.6 , which is within acceptable limits. The reliability coefficient of the questionnaire is 0.870 and, since this value is greater than 0.8 , it indicates high quality of the data. The CITC value is between 0.323 and 0.642 ; since this is above the 0.3 limit, it implies that the data is reliable.The analysis of the validity of the data is shown in Table 5.

Table 5 shows that the KMO $(0.799)$ is greater than the threshold value of 0.6 , thus satisfying the precondition of factor analysis. In addition, the Bartlett sphericity test $(\mathrm{p}<0.55)$ conforms to the appropriate significance level, also indicating suitability of factor analysis.

Table 2. Survey on the impact of investment risk on prefabricated building projects

\begin{tabular}{|c|c|c|c|c|c|c|}
\hline \multirow[b]{2}{*}{ Number } & \multirow{2}{*}{$\begin{array}{l}\text { Item (importance of investment risk } \\
\quad \text { for prefabricated building) }\end{array}$} & \multicolumn{5}{|c|}{ Size } \\
\hline & & $\begin{array}{l}\text { One } \\
\text { point }\end{array}$ & $\begin{array}{l}\text { Two } \\
\text { point }\end{array}$ & $\begin{array}{l}\text { Three } \\
\text { point }\end{array}$ & $\begin{array}{l}\text { Four } \\
\text { point }\end{array}$ & $\begin{array}{l}\text { Five } \\
\text { point }\end{array}$ \\
\hline 1 & The degree of perfection of relevant laws & \multirow{15}{*}{$\begin{array}{l}\text { Completely } \\
\text { unimportant }\end{array}$} & \multirow{15}{*}{$\begin{array}{l}\text { Slightly } \\
\text { unimportant }\end{array}$} & \multirow{15}{*}{$\begin{array}{l}\text { Generally } \\
\text { important }\end{array}$} & \multirow{15}{*}{$\begin{array}{l}\text { Slightly } \\
\text { important }\end{array}$} & \multirow{15}{*}{$\begin{array}{c}\text { Very } \\
\text { important }\end{array}$} \\
\hline 2 & Implementation of incentives or mandatory policies & & & & & \\
\hline 3 & The sustainability and stability of policy & & & & & \\
\hline 4 & Market acceptance & & & & & \\
\hline 5 & Industrial chain integrity & & & & & \\
\hline 6 & The price ratio of the same product & & & & & \\
\hline 7 & $\begin{array}{l}\text { The maneuverability of design, transportation, and } \\
\text { construction schemes }\end{array}$ & & & & & \\
\hline 8 & The integrity of the modular system of the Ministry & & & & & \\
\hline 9 & Quality standard of technical personnel & & & & & \\
\hline 10 & Initial one-time cost and fund recovery period & & & & & \\
\hline 11 & A lack of lists and quotas & & & & & \\
\hline 12 & $\begin{array}{l}\text { Limitations of developer financing and consumer loan } \\
\text { channels }\end{array}$ & & & & & \\
\hline 13 & $\begin{array}{l}\text { Project participation in communication and } \\
\text { coordination among enterprises }\end{array}$ & & & & & \\
\hline 14 & Project management method for prefabricated building & & & & & \\
\hline 15 & Management staff's experience and quality level & & & & & \\
\hline
\end{tabular}


Table 3. Summary of respondents to the questionnaire $(n=210)$

\begin{tabular}{|l|l|c|c|}
\hline \multicolumn{1}{|c|}{ Essential information } & \multicolumn{1}{|c|}{ Classification } & Frequency & Percentage (\%) \\
\hline \multirow{4}{*}{ Age } & 30 years old and below & 22 & 10.48 \\
\cline { 2 - 4 } & $31 \sim 40$ years old & 108 & 51.42 \\
\cline { 2 - 4 } & 41 years old and above & 80 & 38.10 \\
\hline \multirow{3}{*}{ Sex } & Men & 114 & 54.29 \\
\cline { 2 - 4 } & Women & 96 & 45.71 \\
\hline \multirow{3}{*}{ Educational level } & Specialist and below & 10 & 4.76 \\
\cline { 2 - 4 } & Undergraduate & 97 & 46.19 \\
\cline { 2 - 4 } & Master's and above & 103 & 49.05 \\
\hline
\end{tabular}

Table 4. Cronbach's alpha reliability coefficient

\begin{tabular}{|c|c|c|c|c|}
\hline $\begin{array}{c}\text { Latent } \\
\text { variable }\end{array}$ & $\begin{array}{c}\text { Observation } \\
\text { variable }\end{array}$ & $\begin{array}{c}\text { Correction item } \\
\text { total correlation } \\
\text { (CITC) }\end{array}$ & \multicolumn{2}{|c|}{$\begin{array}{l}\text { Alpha } \\
\text { coefficient }\end{array}$} \\
\hline \multirow{3}{*}{$\begin{array}{c}\text { Policy } \\
\text { A }\end{array}$} & A1 & 0.401 & \multirow{3}{*}{0.676} & \multirow{15}{*}{0.870} \\
\hline & A2 & 0.484 & & \\
\hline & A3 & 0.606 & & \\
\hline \multirow{3}{*}{$\begin{array}{c}\text { Market } \\
\text { B }\end{array}$} & B1 & 0.529 & \multirow{3}{*}{0.688} & \\
\hline & B2 & 0.628 & & \\
\hline & B3 & 0.370 & & \\
\hline \multirow{3}{*}{$\begin{array}{c}\text { Technology } \\
\text { C }\end{array}$} & $\mathrm{C} 1$ & 0.420 & \multirow{3}{*}{0.637} & \\
\hline & $\mathrm{C} 2$ & 0.552 & & \\
\hline & $\mathrm{C} 3$ & 0.323 & & \\
\hline \multirow{3}{*}{$\begin{array}{l}\text { Economic } \\
\text { D }\end{array}$} & D1 & 0.497 & \multirow{3}{*}{0.660} & \\
\hline & D2 & 0.456 & & \\
\hline & D3 & 0.460 & & \\
\hline \multirow{3}{*}{$\begin{array}{c}\text { Management } \\
\mathrm{E}\end{array}$} & E1 & 0.572 & \multirow{3}{*}{0.774} & \\
\hline & E2 & 0.624 & & \\
\hline & E3 & 0.642 & & \\
\hline
\end{tabular}

Table 5. Test results of Barthes spherical values (Bartlett) and KMO values

\begin{tabular}{|l|l|c|}
\hline \multicolumn{2}{|l|}{ Inspection index } & Numerical value \\
\hline \multirow{3}{*}{$\begin{array}{l}\text { Bart spherical } \\
\text { value }\end{array}$} & Approximate chi square & 532.878 \\
\cline { 2 - 3 } & $\mathrm{df}$ & 105 \\
\cline { 2 - 3 } & $\mathrm{p}$ value & 0.000 \\
\hline KMO & 0.779 \\
\hline
\end{tabular}

\subsection{Construction and revision of SEM based on Amos 22.0}

The fitting indices before and after model modification are analyzed (Table 6).

The first four parameters in the table are the absolute exponents resulting from fitting the structural equation model, namely the root of the significance, the chi square's degree of freedom ratio, the fitness index, and the approximate error, respectively. The next four are the relative fit exponents, namely the residual mean square root, the comparison fitting index, the increment fitting index, and the Tucker Lewis index. Results from the table indi-
Table 6. SEM model fitting index comparison table

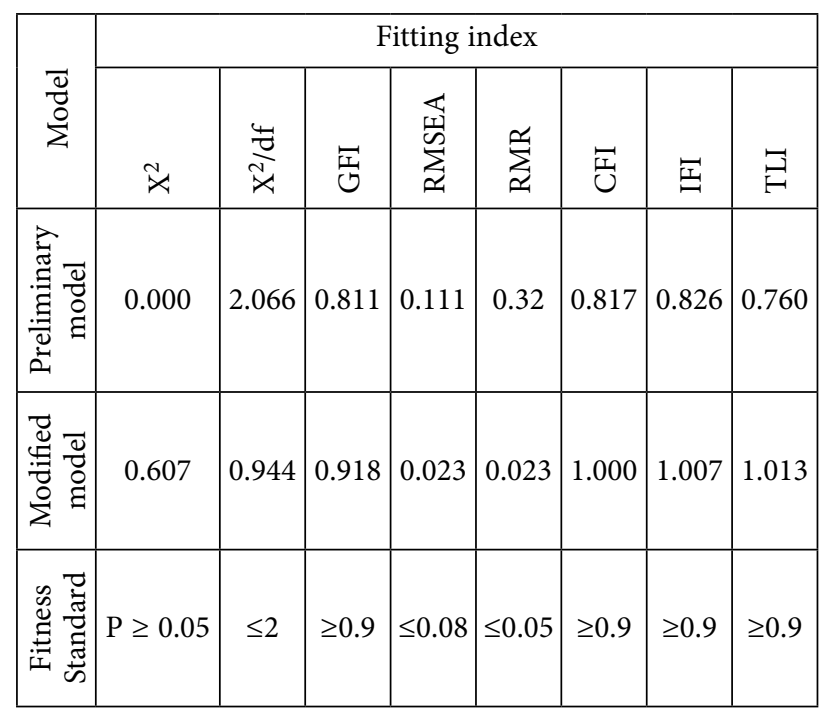

cate that the modified models conform to the appropriate matching standard.

AMOS makes the following three assumptions when analyzing the model: (1) linear relationship, (2) independence of observation value, that is, the sample should be randomly selected, and (3) normal distribution of the observed variables. The test data of the observed variables are shown in Table 7.

Studies, such as the one carried out by Kline (2015), show that in the normality test data of observed variables, if the skewness coefficient is less than 3 and the Kurtosis coefficient is less than 8 , then the data conforms to normal distribution. Table 7 shows that the skewness coefficient of the 15 measured variables is less than 3 , and the kurtosis coefficient is less than 8 , which indicates that the data of the observation variables are normally distributed.

\subsection{Calculation of the weights of the investment risk index}

The investment risk is regarded as a high-level factor, and the path is redrawn as shown in Figure 4.

Suppose a variable corresponds to path $N$ and the coefficients are $X_{1}, X_{2}, \ldots, X_{n}$. The index weight can be calculated according to Eqn (5) and the calculation results are shown in Table 8. 
Table 7. Normality test of measurement variables

\begin{tabular}{|c|c|c|c|c|c|c|}
\hline Variable & Minimum & Maximum & $\begin{array}{l}\text { Skewness } \\
\text { coefficient }\end{array}$ & $\begin{array}{l}\text { Critical } \\
\text { ratio value }\end{array}$ & $\begin{array}{c}\text { Kurtosis } \\
\text { coefficient }\end{array}$ & $\begin{array}{l}\text { Critical } \\
\text { ratio value }\end{array}$ \\
\hline The degree of perfection of relevant laws & 3.000 & 5.000 & 0.792 & 3.769 & -0.362 & -0.861 \\
\hline $\begin{array}{l}\text { Implementation of incentives or mandatory } \\
\text { policies }\end{array}$ & 2.000 & 5.000 & 0.221 & 1.053 & -0.406 & -0.967 \\
\hline The sustainability and stability of policy & 3.000 & 5.000 & 0.644 & 3.068 & -0.558 & -1.329 \\
\hline Market acceptance & 2.000 & 5.000 & 0.670 & 3.192 & -0.339 & -0.807 \\
\hline Industrial chain integrity & 3.000 & 5.000 & 0.597 & 2.842 & -0.777 & -1.849 \\
\hline The price ratio of the same product & 2.000 & 5.000 & 0.225 & 1.073 & -0.572 & -1.361 \\
\hline $\begin{array}{l}\text { The maneuverability of design, transportation, } \\
\text { and construction schemes }\end{array}$ & 1.000 & 5.000 & 0.101 & 0.479 & 0.361 & -0.859 \\
\hline $\begin{array}{l}\text { The integrity of the modular system of the } \\
\text { Ministry }\end{array}$ & 2.000 & 5.000 & 0.065 & 0.307 & -0.353 & -0.841 \\
\hline Quality standard of technical personnel & 3.000 & 5.000 & 0.602 & 2.868 & -0.572 & -1.362 \\
\hline Initial one-time cost and fund recovery period & 2.000 & 5.000 & 0.497 & 2.365 & 0.586 & 1.394 \\
\hline A lack of lists and quotas & 3.000 & 5.000 & 0.696 & 3.314 & -0.503 & 1.198 \\
\hline $\begin{array}{l}\text { Limitations of developer financing and } \\
\text { consumer loan channels }\end{array}$ & 3.000 & 5.000 & 0.564 & 2.687 & -0.625 & -1.487 \\
\hline $\begin{array}{l}\text { Project participation in communication and } \\
\text { coordination among enterprises }\end{array}$ & 3.000 & 5.000 & 0.422 & 2.010 & 0.725 & -1.726 \\
\hline $\begin{array}{l}\text { Project management method for prefabricated } \\
\text { building }\end{array}$ & 1.000 & 5.000 & 0.558 & 2.657 & 0.463 & 1.101 \\
\hline Management staff's experience and quality level & 2.000 & 5.000 & 0.732 & 3.484 & -0.159 & -.378 \\
\hline Multivariate & & & & & 10.171 & 1.825 \\
\hline
\end{tabular}

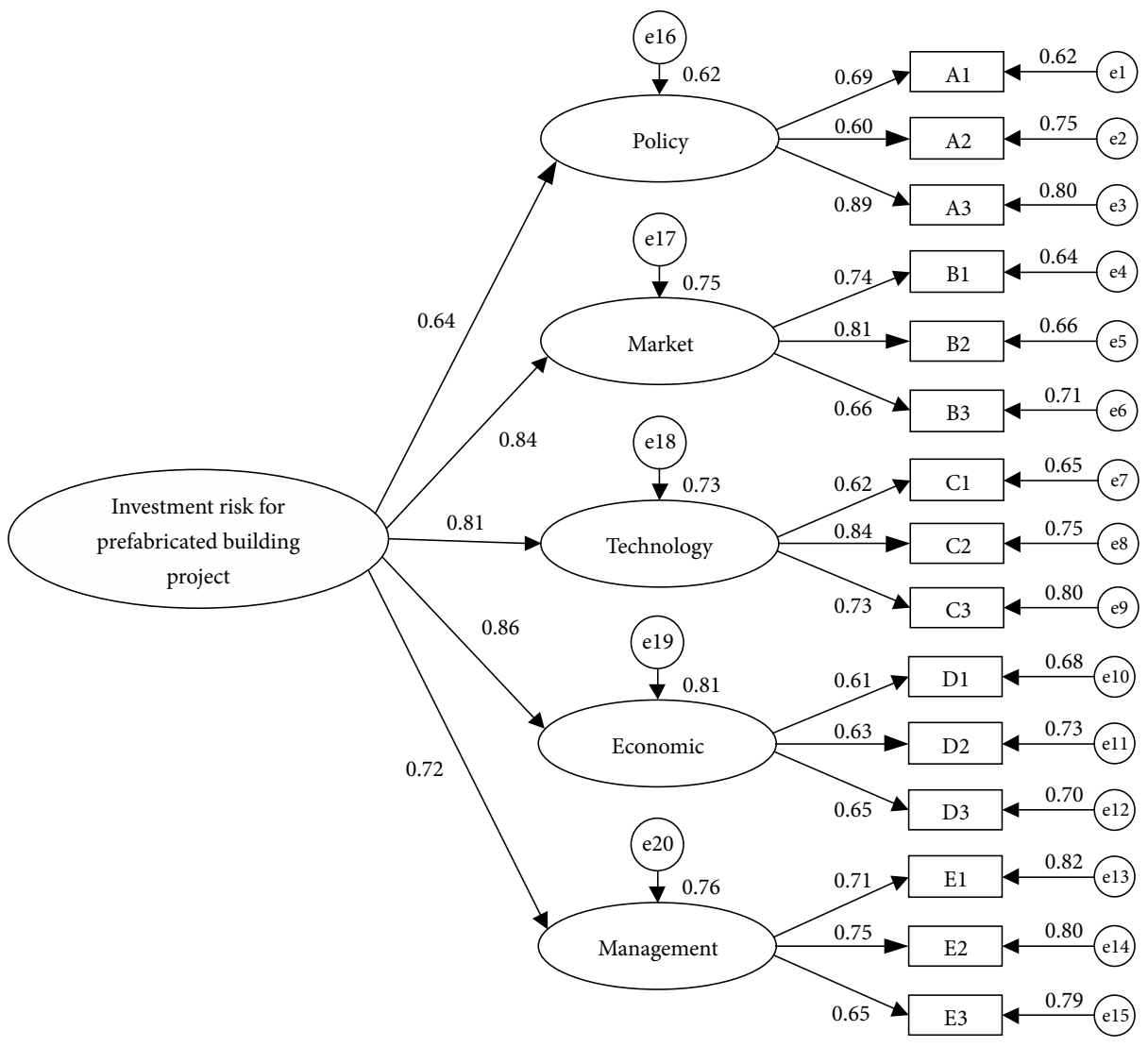

Figure 4. High-order model of investment risk evaluation for a project of prefabricated building construction 
Table 8. Investment risk evaluation system for assembled building projects (including weights)

\begin{tabular}{|c|c|c|c|c|}
\hline $\begin{array}{l}\text { First level of } \\
\text { evaluation index }\end{array}$ & Weight & Second level of evaluation index & $\begin{array}{l}\text { The weight of the first- } \\
\text { grade index }\end{array}$ & $\begin{array}{l}\text { Comprehensive } \\
\text { weight }\end{array}$ \\
\hline \multirow{3}{*}{ Policy system } & \multirow{3}{*}{0.179} & The degree of perfection of relevant laws & 0.188 & 0.034 \\
\hline & & Implementation of incentives or mandatory policies & 0.366 & 0.066 \\
\hline & & The sustainability and stability of policy & 0.446 & 0.080 \\
\hline \multirow{3}{*}{ Market system } & \multirow{3}{*}{0.196} & Market acceptance & 0.388 & 0.076 \\
\hline & & Industrial chain integrity & 0.392 & 0.077 \\
\hline & & The price ratio of the same product & 0.220 & 0.043 \\
\hline \multirow{3}{*}{ Technical system } & \multirow{3}{*}{0.200} & $\begin{array}{l}\text { The maneuverability of design, transportation, and } \\
\text { construction schemes }\end{array}$ & 0.366 & 0.073 \\
\hline & & The integrity of the modular system of the Ministry & 0.426 & 0.085 \\
\hline & & Quality standard of technical personnel & 0.208 & 0.042 \\
\hline \multirow{3}{*}{ Economic system } & \multirow{3}{*}{0.244} & Initial one-time cost and fund recovery period & 0.366 & 0.089 \\
\hline & & A lack of lists and quotas & 0.308 & 0.075 \\
\hline & & $\begin{array}{l}\text { Limitations of developer financing and consumer loan } \\
\text { channels }\end{array}$ & 0.326 & 0.080 \\
\hline \multirow{3}{*}{$\begin{array}{l}\text { Management } \\
\text { system }\end{array}$} & \multirow{3}{*}{0.181} & $\begin{array}{l}\text { Project participation in communication and } \\
\text { coordination among enterprises }\end{array}$ & 0.319 & 0.058 \\
\hline & & Project management method for prefabricated building & 0.355 & 0.064 \\
\hline & & Management staff's experience and quality level & 0.326 & 0.059 \\
\hline
\end{tabular}

$$
X_{i}=\frac{x_{i}}{\sum_{i=1}^{n} x_{i}}
$$

The weight list in this survey shows that the economic system has the most prominent impact on the investment risk of prefabricated building projects. The varying levels of influence, from high to low, are of economy, technology, market, management, and policy. The highest relative comprehensive weights are those of initial one-time cost and fund recovery period, the integrity of the modular system of the Ministry, the sustainability and stability of policy, and limitations of developer financing and consumer loan channels.

\section{Case analysis}

A real estate company plans to develop a prefabricated building project, which involves the use of a prefabricated concrete frame shear wall structure. The monomer prefabrication rate is over $25 \%$, the planned building area is $53,100 \mathrm{~m}^{2}$, the underground floor has two layers, the ground floor has 15 layers, and the structure height is $46.3 \mathrm{~m}$.

On the basis of market research and analysis, the enterprise has formulated four development plans, which are different in design, financing, and management, and have their own advantages. For decision-makers, reasonable investment decisions are particularly important. To ensure optimum implementation of the program, and to conduct risk management activities effectively, the enterprise selected a specific set of risk evaluation indicators and invited experts to score the programs. The expert scoring system adopts the score of the ten-point system; the higher the score, the greater is the risk value of the index. The overall results of the four expert ratings are shown in Table 9.

Using the index of each plan and the corresponding weight, the respective comprehensive risk score can be calculated. The resulting scores are, from largest to smallest, scheme one (5.931), scheme four (5.857), scheme three (5.735), and scheme two (5.482). Thus, scheme three has the lowest comprehensive investment risk.

The comprehensive risk score of scheme four is the largest due to elements such as the sustainability and stability of the policy, the modular system of the Ministry, the one-time cost and the period of capital recovery, and the financing and loan channels.

Analyzing the index reveals that the stability and sustainability of the policy are the main factors affecting the policy level; market acceptance and industrial chain integrity are the main factors affecting the market level; the operability of various technical schemes and the model number system are the main factors of the technical level. At the economic level, the influence of each index is greater. At the management level, the impact of each indicator is similar. The weights of the three indicators, namely the degree of perfection of the law, the price of the product, and the standard of the technical personnel, are too low, possibly introducing some errors.

\section{Investment risk mitigation countermeasure}

\subsection{Investment risk mitigation for policy measures}

It is necessary to modify and supplement existing laws and regulations, apply the list and quota of prefabricated buildings, and speed up updates (Chang et al., 2018). On the one hand, incentive measures can be increased by providing certain subsidies or profits for the development of pre- 
Table 9. Risk assessment for the construction of a prefabricated building project

\begin{tabular}{|c|c|c|c|c|c|}
\hline \multirow{2}{*}{$\begin{array}{l}\text { Comprehensive } \\
\text { weight }\end{array}$} & \multirow{2}{*}{ Evaluation index } & \multicolumn{4}{|c|}{ Scheme and its score } \\
\hline & & Scheme one & Scheme two & Scheme three & Scheme four \\
\hline 0.034 & The degree of perfection of relevant laws & 8 & 7 & 6 & 7 \\
\hline 0.066 & Implementation of incentives or mandatory policies & 6 & 7 & 4 & 5 \\
\hline 0.080 & The sustainability and stability of policy & 5 & 5 & 7 & 6 \\
\hline 0.076 & Market acceptance & 3 & 4 & 6 & 6 \\
\hline 0.077 & Industrial chain integrity & 4 & 5 & 6 & 7 \\
\hline 0.043 & The price ratio of the same product & 7 & 5 & 4 & 5 \\
\hline 0.073 & $\begin{array}{l}\text { The maneuverability of design, transportation, and } \\
\text { construction schemes }\end{array}$ & 6 & 6 & 7 & 8 \\
\hline 0.085 & The integrity of the modular system of the Ministry & 7 & 6 & 5 & 4 \\
\hline 0.042 & Quality standard of technical personnel & 6 & 4 & 5 & 7 \\
\hline 0.089 & Initial one-time cost and fund recovery period & 8 & 5 & 6 & 3 \\
\hline 0.075 & A lack of lists and quotas & 6 & 7 & 5 & 7 \\
\hline 0.080 & $\begin{array}{l}\text { Limitations of developer financing and consumer loan } \\
\text { channels }\end{array}$ & 4 & 4 & 7 & 5 \\
\hline 0.058 & $\begin{array}{l}\text { Project participation in communication and } \\
\text { coordination among enterprises }\end{array}$ & 7 & 6 & 8 & 8 \\
\hline 0.064 & Project management method for prefabricated building & 7 & 5 & 4 & 6 \\
\hline 0.059 & Management staff experience and quality level & 7 & 7 & 5 & 6 \\
\hline
\end{tabular}

fabricated construction projects. On the other hand, there is a need for incentives for the prefabricated component factories. The production of components achieves value addition and results in value-added tax, and this should take appropriate tax rate subsidies to control. Finally, in terms of financial policy, it is necessary to provide appropriate preferential loan interest rates for the enterprises that are involved with prefabricated building projects. At the same time, consumers who buy prefabricated housing and other projects should be encouraged to buy such policies at low down-payment and priority lending. We should aim to strengthen the promotion of the policy as well and expand the scope of projects that must take the form of prefabricated building development in order to promote industrial development.

\subsection{Investment risk mitigation for market measures}

When it comes to improving the cost performance of building products, the advantages of prefabricated buildings, compared to traditional buildings, include not only reduced construction times but also reduced environmental pollution, and consumption of energy, water, and other resources in later operations and management of the buildings (Navaratnam et al., 2019). In case the development cost cannot be effectively controlled, the building can be further developed along the direction of green construction, with energy conservation and environmental protection as its focus, to improve the potential cost performance. This can help strengthen consumers' cognition and improve market acceptance (Research and Markets, 2018).

\subsection{Investment risk mitigation for technical measures}

Under the premise of reasonable control of building modulus, the unity between parts, components, and buildings is strong. This helps realize standardized and large-scale production systems (Pons \& Wadel, 2011). The establishment of modulization depends on the perfection and coordination of modulization systems that need the support of standards (Lau et al., 2019). In a sound module system, the reuse rate of materials such as templates with the same specification increases, which has a significant effect on reducing costs. Achieving the integration and standardization of components and parts can lead to an improvement in the quality standards of products and requires close contact between enterprises, which can avoid problems in project implementation. Prefabricated buildings are different from traditional buildings because of the difficulty of component hoisting and the high-quality requirements of building products; this implies that an improvement in construction technology is also necessary.

\subsection{Investment risk mitigation for economic measures}

The investment payback period of construction projects is long, while the pre-construction investment of prefabricated building projects is high, and the demand for capital is urgent. In addition to careful analysis of fund-raising channels, reasonable arrangements should be made for the investment of funds, which will not affect the implementation progress of the project (Couto et al., 2018). While 
fundraising, enterprises should choose the most appropriate way to reduce the cost of financing (Navaratnam et al., 2019; Li et al., 2014). In addition, when estimating the development cost of the prefabricated building project, the enterprise should fully evaluate and draw lessons from existing projects, consider interference factors, and make the cost estimate as close to the actual cost as possible.

\subsection{Investment risk mitigation for management measures}

First, there must be participation in the full coordination between enterprises, such as the prefabrication plant and the developer, to negotiate the production (Steinhardt \& Manley, 2016). Second, there should be some project management methods suitable for prefabricated building projects by improving traditional construction project management modes (Tumminia et al., 2018). Finally, the experience and skills of the management personnel are important, as they should select participants stringently manner and invest in training them (Kildsgaard et al., 2013).

\section{Notations}

\section{Variables and functions}

$X$ - the external derivative observation index;

$Y$ - the internal derivative observation index;

$\delta$ - the measurement error of the independent variable;

$\varepsilon$ - the measurement error of the dependent variable;

$\xi$ - the external deflected potential variable;

$\eta$ - the internal deflected potential variable;

$\Lambda x$ - the relationship between $X$ and $\xi$;

$\Lambda_{Y}$ - the relationship between $Y$ and $\eta$;

$\Gamma$ - the influence of the independent variable on the dependent variable;

$B$ - the relationship between dependent variables;

$\zeta$ - the residual term of the structural equation;

$p$ - the number of exogenous observation variables;

$q$ - the number of endogenous observation variables.

\section{Abbreviations \\ SEM - Structural Equation Model; \\ MLE - Maximum Likelihood Estimation; \\ CITC - Correction Item Total Correction.}

\section{Conclusions}

Prefabricated buildings have certain advantages over traditional construction, such as improved construction quality, reduced labor force requirements, and lower environmental impact. However, the prefabricated project construction industry in China has generally witnessed great investment risk in its early stages, and there is the need for a systematic planning method to minimize this risk. It is necessary to analyze the influencing factors of this risk and assess states for prefabricated building projects to ensure that effective solutions help reduce the impact led by using limited resources.

This paper investigates the influencing factors on investment risk of prefabricated building construction based on a series of surveys in China. Data were collected through a questionnaire survey, and SPSS was used to test the validity and reliability, after which preliminary evaluation indexes were selected. The index evaluation system was constructed based on the SEM, including 5 first-level and 15 second-level factors. The SEM integrates all major variables affecting the investment risk of prefabricated building projects and is capable of studying the behavior of these potential variables from an influencing perspective. These assessments cover different risk factors resulting from policy, markets, technical, economic, and management system risks. Research results show that the highest influence was that of economy, followed by technology, market, management, and policy. This paper proposes a method based model as an effective instrument to measure and assess the investment risk of prefabricated building projects. The principle factors make it more focused for decision-makers when making relevant measures to reduce the negative impact of prefabricated buildings. The suggested solutions provide useful references for decision-makers to improve the efficiency of the measures. Compared to other studies, the advantage of the proposed analysis in simplifying and integrating the SEM-based investment risk assessment data is evident. The evaluation and analysis of the prefabricated building investment risk during the construction processes can provide not only a theoretical reference to control risk management, but also practical significance for risk reduction policies and regulations for governments and enterprises.

Although the objectives of this study were achieved, some limitations exist. First, this study collected the opinions of the respondents, which were based on their experiences and were therefore subjective. Second, the findings from this study are applicable to the context of China exclusively, and may not be applicable in other countries. Nonetheless, the findings from this study are valuable, as they offer initial investigation into influencing factors in this construction segment. The data applied for the analysis was obtained from the prefabricated building projects in China, but the research is also valuable for conducting similar studies on risks to investment in projects in other regions. Furthermore, the findings from this study can benefit the industry decision-makers by providing industry practitioners with investment risk control methods for prefabricated building construction, ultimately helping them achieve better efficiency of the measures in the future. For further research, investment risk from prefabricated building construction in other areas should be considered, as well as the establishment of an accurate risk evaluation method for prefabricated building projects. 


\section{Acknowledgements}

This work was supported by the $<$ Department of Science and Technology of Fujian Province of China $>$ under Grant [number 2019R0032]; and <Ministry of Educaton of the People's Republic of China> under Grant [number20XJC630068].

\section{Funding}

This work was supported by the <Department of Science and Technology of Fujian Province of China $>$ under Grant [number 2019R0032]; and <Ministry of Educaton of the People's Republic of China $>$ under Grant [number20XJC630068].

\section{Disclosure statement}

The author declares that they have no know competing financial interests or personal relationships that could have appeared to influence the work reported in this paper.

\section{References}

Bollen, K. A. (1989). Structural equations with latent variables. John Wiley \& Sons, Inc. https://doi.org/10.1002/9781118619179

Burtonshaw-Gunn, S. A. (2017). Risk and financial management in construction. Gower Publishing, Ltd. https://doi.org/10.4324/9781315244112

Cen, Y., \& Liu, M. X. (2016). Evaluation and suggestion on economic policy of prefabricated building. Housing Industry, 9.

Chang, C., \& Wu, X. (2019, February). Research on safety cost optimization model of prefabricated building. In Z. Xu, K.-K. Choo, A. Dehghantanha, R. Parizi, M. Hammoudeh (Eds.), Cyber Security Intelligence and Analytics (CSIA 2019). Advances in Intelligent Systems and Computing (Vol. 928, pp. 1268-1273). Springer, Cham.

https://doi.org/10.1007/978-3-030-15235-2_171

Chang, Y., Li, X., Masanet, E., Zhang, L., Huang, Z., \& Ries, R. (2018). Unlocking the green opportunity for prefabricated buildings and construction in China. Resources Conservation and Recycling, 139, 259-261.

https://doi.org/10.1016/j.resconrec.2018.08.025

Chen, Y., Du, X. J., \& W. Y. (2017). Establishment and method of risk assessment system for prefabricated buildings. Value Engineering, 28, 16-19.

Cheng, Q. Z. (2017). Investment control of prefabricated building. Urbanism and Architecture, 5, 210-211. https://doi.org/10.3969/j.issn.1673-0232.2017.05.190

Cho, K., Hong, T., \& Hyun, C. (2009). Effect of project characteristics on project performance in construction projects based on structural equation model. Expert Systems with Applications, 36(7), 10461-10470.

https://doi.org/10.1016/j.eswa.2009.01.032

Couto, J. P., Mendonca, P., \& Reis, A. P. (2018). Prefabricated building systems: Evaluation of the construction practitioners' perception on the environmental and economic benefits. Environmental Engineering and Management Journal, 17(9), 2103-2115. https://doi.org/10.30638/eemj.2018.209

Debrezion, G., Pels, E., \& Rietveld, P. (2007). The impact of railway stations on residential and commercial property value: A meta-analysis. The Journal of Real Estate Finance and Economics, 35(2), 161-180. http://doi.org/10.1007/s11146-007-9032-Z
Fischinger, M., Kramar, M., \& Isaković, T. (2009). Seismic safety of prefabricated reinforced-concrete halls-analytical study. Gradevinar, 61(11), 1039-1045.

Gang, X. W. (2016). Discussion on construction project management method in real estate development. China Venture Capital, 6, 94.

Haavelmo, T. (1943). The statistical implications of a system of simultaneous equations. Econometrica, 11(1), 1-12. https://doi.org/10.2307/1905714

Hong, J., Shen, G. Q., Li, Z., Zhang, B., \& Zhang, W. (2018). Barriers to promoting prefabricated building in China: A costbenefit analysis. Journal of Cleaner Production, 172, 649-660. https://doi.org/10.1016/j.jclepro.2017.10.171

Huang, Y. X., Zhu, L., Ye, Z. X., Wang, Y, Q., \& Shi, Y. J. (2013). Summary of research on connection mode of precast concrete structure. Concrete, 1, 120-126. https://doi.org/10.3969/j.issn.1002-3550.2013.01.033

Inozemtcev, A., \& Duong, T. Q. (2019). Technical and economic efficiency of materials using $3 \mathrm{D}$-printing in construction on the example of high-strength lightweight fiber-reinforced concrete. In XXII International Scientific Conference "Construction the Formation of Living Environment" (FORM-2019). Tashkent, Uzbekistan. https://doi.org/10.1051/e3sconf/20199702010

Iqbal, S., Choudhry, R. M., Holschemacher, K., Ali, A., \& Tamošaitiene, J. (2015). Risk management in construction projects. Technological and Economic Development of Economy, 21(1), 65-78. https://doi.org/10.3846/20294913.2014.994582

Kaliszewski, J. (2019). The project of building a concrete prefabrication plant using the innovative production technologies (Doctoral dissertation). Instytut Organizacji Systemów Produkcyjnych.

Kildsgaard, I., Jarnehammar, A., Widheden, A., \& Wall, M. (2013). Energy and environmental performance of multistory apartment buildings built in timber construction using passive house principles. Buildings, 3(1), 258-277. https://doi.org/10.3390/buildings3010258

Kline, R. B. (2015). Principles and practice of structural equation modeling. Guilford Publications.

Lai, Z. M. (2018). Investment risk analysis of prefabricated building in China market. Housing and Real Estate, 493(8), 19.

Lau, S. Y., Chen, T., Zhang, J., Xue, X., Lau, S. K., \& Khoo, Y. S. (2019, July). A new approach for the project process: prefabricated building technology integrated with photovoltaics based on the BIM system. In IOP Conference Series: Earth and Environmental Science (Vol. 294). Tokyo, Japan. https://doi.org/10.1088/1755-1315/294/1/012050

Li, Y. L. (2017). Investment cost analysis of assembled steel structure housing. Engineering Economy, 27(12), 9-12.

Li, Z., Shen, G. Q., \& Xue, X. (2014). Critical review of the research on the management of prefabricated building. Habitat International, 43, 240-249.

https://doi.org/10.1016/j.habitatint.2014.04.001

Li, C. Z., Hong, J., Xue, F., Shen, G. Q., Xu, X., \& Mok, M. K. (2016). Schedule risks in prefabrication housing production in Hong Kong: a social network analysis. Journal of Cleaner Production, 134, 482-494. https://doi.org/10.1016/j.jclepro.2016.02.123

Li, C. Z., Shen, G. Q., Xu, X., Xue, F., Sommer, L., \& Luo, L. (2017a). Schedule risk modeling in prefabrication housing production. Journal of Cleaner Production, 153, 692-706. https://doi.org/10.1016/j.jclepro.2016.11.028 
Li, M., Li, G., Huang, Y., \& Deng, L. (2017b). Research on investment risk management of Chinese prefabricated construction projects based on a system dynamics model. Buildings, 7(3), 83. https://doi.org/10.3390/buildings7030083

Liu, Y. (2013). Financing risk management of construction investment projects. Urban Construction Theory Research, 16, $16-19$.

Liu, K., Zhao, P., \& Wang, H. (2017). Application of SEM based prefabricated concrete structure. Journal of Civil Engineering and Management, 34(1), 106-112.

Luo, L. (2019). Modelling risks in the supply chains of prefabricated building projects in Hong Kong (Doctoral dissertation). The Hong Kong Polytechnic University.

Luo, L. Z., Mao, C., Shen, L. Y., \& Li, Z. D. (2015). Risk factors affecting practitioners' attitudes toward the implementation of an industrialized building system. Engineering, Construction and Architectural Management, 22(6), 622-643. https://doi.org/10.1108/ECAM-04-2014-0048

Molenaar, K., Washington, S., \& Diekmann, J. (2000). Structural equation model of construction contract dispute potential. Journal of Construction Engineering and Management, 126(4), 268-277.

https://doi.org/10.1061/(ASCE)0733-9364(2000)126:4(268)

Navaratnam, S., Ngo, T., Gunawardena, T., \& Henderson, D. (2019). Performance review of prefabricated building systems and future research in Australia. Buildings, 9(2), 38. https://doi.org/10.3390/buildings9020038

Ng, A., \& Loosemore, M. (2007). Risk allocation in the private provision of public infrastructure. International Journal of Project Management, 25(1), 66-76.

https://doi.org/10.1016/j.ijproman.2006.06.005

Nistico, N., Gkagka, E. E., \& Gantes, C. J. (2015). Roof isolation with tuned mass-based systems and application to a prefabricated building. Arabian Journal for Science and Engineering, 40(2), 431-442. https://doi.org/10.1007/s13369-014-1537-1

Pearl, J. (2009). Causality. Cambridge University Press. https://doi.org/10.1017/CBO9780511803161

Pinto, A. (2014). QRAM a qualitative occupational safety risk assessment model for the construction industry that incorporate uncertainties by the use of fuzzy sets. Safety Science, 63, 57-76. https://doi.org/10.1016/j.ssci.2013.10.019

Pons, O., \& Wadel, G. (2011). Environmental impacts of prefabricated school buildings in Catalonia. Habitat International, 35(4), 553-563.

https://doi.org/10.1016/j.habitatint.2011.03.005

Qi, B. K., \& Zhu, Y. (2015). Research on risk assessment method of prefabricated building. Project Cost Management, 4, 30-33.

Research and Markets. (2018). Prefabricated volumetric buildings market report - UK 2014-2018.

http://www.researchandmarkets.com/research/tfr943/prefabricated.

Qi, B. K., Zhu, Y., \& Fan, W.Y. (2016). Life cycle risk identification method for assembled building. Journal of Shenyang Construction University: Social Science Edition, 3, 7.

Rong, T. S. (2009). Amos and research methods. Chongqing University Press.

Rose, L. R. (2012). Risk management project for work with precast concrete shells. Work, 41(Supplement 1), 4157-4162. https://doi.org/10.3233/wor-2012-0712-4157

Steinhardt, D. A., \& Manley, K. (2016). Adoption of prefabricated housing - the role of country context. Sustainable Cities and Society, 22, 126-135. https://doi.org/10.1016/j.scs.2016.02.008
Stroebele, B. S., Kiessling, A. J., \& Zhang, J. (2017). Impact analysis of complexity drivers in the supply chain of prefabricated houses. Journal of Management and Strategy, 8(1), 1-9. https://doi.org/10.5430/jms.v8n1p1

Tian, D., Li, X. W., \& Ma, T. (2016). Design and analysis of assembled concrete building component system based on BIM. Building Structure, 17.

Tumminia, G., Guarino, F., Longo, S., Ferraro, M., Cellura, M., \& Antonucci, V. (2018). Life cycle energy performances and environmental impacts of a prefabricated building module. Renewable and Sustainable Energy Reviews, 92, 272-283. https://doi.org/10.1016/j.rser.2018.04.059

Wang, T., Gao, S., Li, X., \& Ning, X. (2018). A meta-networkbased risk evaluation and control method for industrialized building construction projects. Journal of Cleaner Production, 205, 552-564. https://doi.org/10.1016/j.jclepro.2018.09.127

Wang, Z. L., Shen, H. C., \& Zuo, J. (2019). Risks in prefabricated buildings in China: importance-performance analysis approach. Sustainability, 11(12), 3450.

https://doi.org/10.3390/su11123450

Wei, Z. B., Zhu, G. R., \& Ma, N. (2005). Predict model for construction safety accident based on fuzzy judgment. China Occupational Safety and Health Management System Certification, 1(6), 55-57.

Wen, M. (2016). Application research on cost risk management of fabricated concrete residential building project (Master's thesis). Hunan Agricultural University.

Wright, S. (1921). Correlation and causation. Journal of Agricultural Research, 20(7), 557-585.

Wu, G., Duan, K., Zuo, J., Zhao, X., \& Tang, D. (2017). Integrated sustainability assessment of public rental housing community based on a hybrid method of AHP-Entropy weight and cloud model. Sustainability, 9(4), 603. https://doi.org/10.3390/su9040603

Xiong, J. S., Qin, H. T., Li, J. H., \& Zhang, L. (2013). Method of determining index weight in security risk evaluation based on information entropy. Journal of Systems Science, 21(2), 82-84.

Ye, S., \& Tiong, R. L. (2003). The effect of concession period design on completion risk management of BOT projects. Construction Management and Economics, 21(5), 471-482. https://doi.org/10.1080/0144619032000073488

Zhang, J. R. (2014). Investment risk analysis of prefabricated building in Chinese market. Financial Circles, 7, 99.

Zhang, Z. Y., \& Zheng, J. (2015). Analysis of the main points of prefabricated building design. Housing Industry, 9, 10-16.

Zhao, L., Liu, Z., Zhang, H., \& Mbachu, J. (2019). Developing a BIM-based framework for supplier selection in prefabrication. Preprints, 2019030188.

https://www.preprints.org/manuscript/201903.0188/v1

Zheng, S. Q., Wang, D. F., Zuo, Q. L., \& He, Q. (2016). Research on Influencing Factors of prefabricated building cost based on SEM. Project Management Technology, 14(11), 45-49.

Zhong, R. Y., Peng, Y., Xue, F., Fang, J., Zou, W., Luo, H., \& Huang, G. Q. (2017). Prefabricated construction enabled by the Internet-of-Things. Automation in Construction, 76, 59-70. https://doi.org/10.1016/j.autcon.2017.01.006 